Sustainability, Agri, Food and Environmental Research, (ISSN: 0719-3726), 10(X), 2022:

http://dx.doi.org/

\title{
Folding house.
}

\section{Casa plegable}

Aarif. A., Sadik Hussain*, K.S. Juby, C. Karthika , S. Anupama

Civil Engineering Department, Rajadhani Institute of Science and Technology, Palakkad, India

* Corresponding mail id: 11170077@ammini.edu.in

\begin{abstract}
Nowadays there is massive use of concrete in construction industry. To overcome this, new construction techniques and material is adopted for good living standard. Folding house is a technique that considered all the factors like sufficient space for living, economy, environmental issues and living standard. The tendency for the cost effective and quicker construction pushed the folded structures made in reinforced concrete, and led to the construction realized in wood, steel and other modern materials that eventually experienced expansion. In this project we are introducing a cost effective folding house.
\end{abstract}

Keywords: folding house, cost effective and quicker construction.

\section{RESUMEN}

Hoy en día existe un uso masivo del hormigón en la industria de la construcción. Para superar esto, se adoptan nuevas técnicas y materiales de construcción para un buen nivel de vida. La casa plegable es una técnica que considera todos los factores como espacio suficiente para vivir, economía, problemas ambientales y nivel de vida. La tendencia a la construcción rentable y más rápida empujó las estructuras plegadas hechas en hormigón armado, y condujo a la construcción realizada en madera, acero y otros materiales modernos que eventualmente experimentaron expansión. En este proyecto, presentamos una casa plegable rentable.

Palabras clave: casa plegable, construcción rentable y más rápida.

\section{INTRODUCTION}

When we examine the past two years, we are faced with floods that have deeply impacted various regions of our country. Severe floods affects Kerala for the past two years due to unusually high rainfall during the monsoon season. Economic and environmental damages incurred have included infrastructure disruption, and residential and other types of building destruction after such disasters. During disasters, victims cannot be relocated 
Sustainability, Agri, Food and Environmental Research, (ISSN: 0719-3726), 10(X), 2022:

http://dx.doi.org/

quickly to new permanent housing that needs long time for construction or cannot be returned to their own houses because repair in short-time is not feasible. Folding House is a concept to afford homes for peoples in their budget. This concept is totally based on economy, living for homeless and foldability. This house has been designed with considerations of nominal sizes of various units of house and technical installations such as electrical and water systems.

There is no limit to the number of modules that can be assembled, so it is possible to build houses of various sizes. To install it, you don't need a concrete base: it can be placed directly on the floor - as long as it is level. For those who want to fix their residence in a place for long periods, it is advisable to build the house on foundation stakes. The structures can be customized with solar panels, gray water treatment systems, and LED lighting. In standard production, the exterior walls are lined with wood veneers. There are other types of finish, such as plaster, aluminum, natural fiber and marble fillets.

\section{CONSTRUCTION OF FOLDING HOUSE}

A folding house comprising component elements which constitute, in a folded up position of the house, a closed and sealed container in which container are folded up all other component elements of the house, lateral walls of the container in the folded up position of the housing being formed by panels of a floor of the house while an upper wall of the container is formed by panels constituting corbelling walls of the house in the opened out position of the house. The folding house offers many construction options based on multiple modules and materials. The availability of modules of varying sizes, and the ability to add to them laterally allows you an endless array of creative choices. In addition, with its highly standardized production process and dry assembly structure, we can save both time and money[K] Huntington;2010]

\section{METHOD OF OPERATION}

Floors, walls, and ceilings are generally three distinct components which delineate space within a house and are generally represented as such. The floor is folded into the wall which is folded into the ceiling, creating a continuity between the components and between the spaces created. Each of the folds layer and slip past each other in order to delineate space and the movement through space.Folding creates a strong directionality by focusing 
Sustainability, Agri, Food and Environmental Research, (ISSN: 0719-3726), 10(X), 2022:

http://dx.doi.org/

movement through the spaces towards the openings at each end of the fold.

The folds themselves have been relieved of their structural responsibility to the house as a whole. The folds sit on and hang from the frame members. A regular grid has been created. However, based on the position of the folds and how they have been shifted, the grid can adapt. Frame members can be moved orremoved all together. The frame is always exterior. As the folds slip past and between the frames, so do the enclosures. The next layer of folding is at a smaller scale than that of the main folds. Each frame is provided with hinges and when a fold slips into another it joins like a interlock and is then screwed and bolted. The frame is made of galvanized steel structures. The panel walls are made up of sandwich panel which are embedded with facilities for electricity, water supply and to place furniture .The plumbing is prebuilt, but we need to join the outside the water system and septic tank. PPR and PVC water supply anddrainage pipe with fittings are provided. The subfloor is given by fibre cement board. Bathroom floor is provided by PVC floor. Additional plastering can be provided for finishing. The structure is fitted in the concrete stakes for stability. The window is made up of Aluminum alloy double-layer hollow glass window with screens and the door is of Aluminum alloy double-layer hollow glass door. Fig 1 and 2 shows the model made by plywood

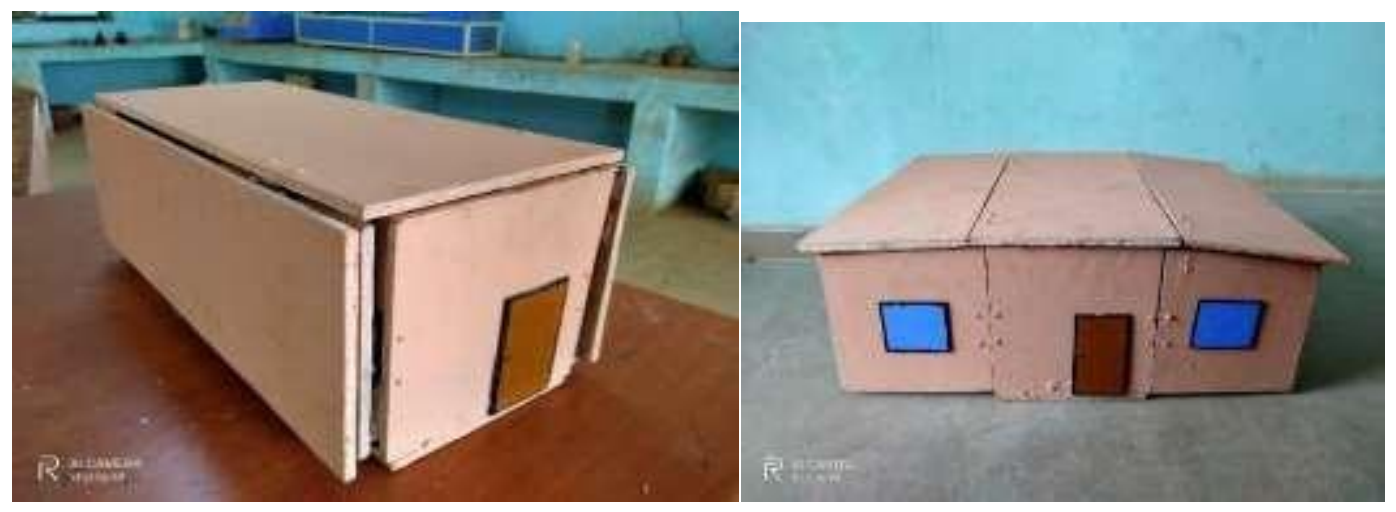

Fig 1 folding house before installation

Fig 2 folding house after installation

PLAN

The figure 3.1 shows the front and top view of the proposed folding house while on unfolded state. Which contains one Living combined dining room, one kitchen, two bed room and one common bathroom

Total plinth area $=57.90 \mathrm{~m}^{2}$ 
Sustainability, Agri, Food and Environmental Research, (ISSN: 0719-3726), 10(X), 2022: http://dx.doi.org/

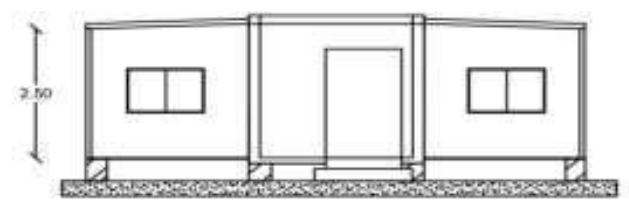

FRONT ELEVATION

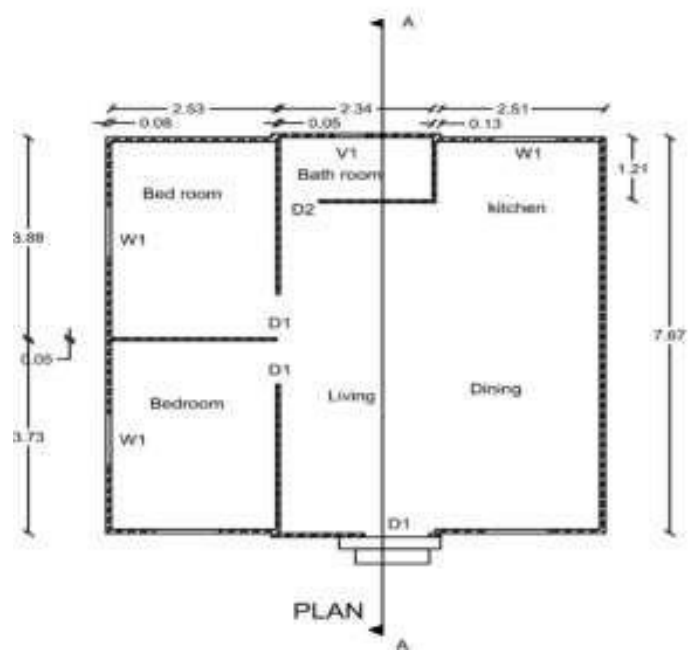

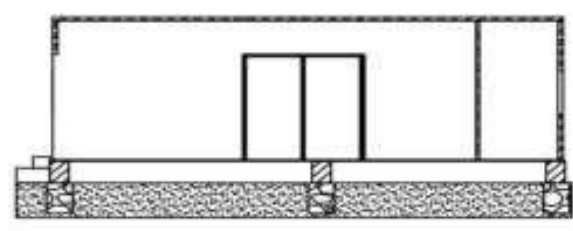

SECTION A-A

\begin{tabular}{|c|c|c|c|}
\hline MEANEK & TEM & BAZE. & nos \\
\hline DI & oocrs & 1000000 & 3 \\
\hline$D 2$ & ODOR & 100x200 & $\mathrm{t}$ \\
\hline wi & monoon's & $156 x+20$ & 3 \\
\hline $\mathrm{vI}$ & VENTILATOR & 100060u & 1 \\
\hline
\end{tabular}

"ALL OMMENSIONS ARE IN METERE"

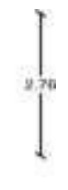

\section{.}

Fig 3 Plan of the house

\section{ESTIMATION}

Estimation of the house is done by sampling. By reducing the massive use of steel and concrete we can reduce the total cost of the project by replacing it with the new materials like steel, fibre cement concrete $\&$ roofing material. If we are thinking to make this project in large scale then total cost can be minimized by proper planning and discounts given by material seller.

TABLE 1

\begin{tabular}{ccc}
\hline \multicolumn{2}{l}{ Estimation of Folding House } & \\
\hline SIno & \multicolumn{1}{c}{ Type of work } & Amount(Rs \\
& Cleaning and leveling site and Piling & 10,850 \\
1 & Sandwitch panel of walls, floor and roof & 182,000 \\
2 & Steel frame & 36,000 \\
3 & Door and windows & 30,000 \\
5 & Painting and Plumbing & 50,000 \\
6 & Electrification, drainage & 50,000 \\
7 & Misc (Including Labour and Transportation) & 30,000 \\
\hline
\end{tabular}


Sustainability, Agri, Food and Environmental Research, (ISSN: 0719-3726), 10(X), 2022: http://dx.doi.org/

\section{STRUCTURAL CONSIDERATIONS IN DESIGNING OF HOUSE}

The structural systems are jointed via bolts or screws. The systems are composed of materials such as prefabricated cardboard tubes, sandwich panels, and also materials made of timber, had no prefabricated characteristic or cement-wood shavings mixture named chip panel. Their foundations may compose of concrete or sandbag crates. Modular system for temporary housing can be made of wood-based products and may be supported by steel mechanical frames. Well-designed joints, beam, wall and floor system increase the strength. Also while thermal and structural performance can be increased and labour cost and construction time can be decreased using panelized systems. [ Conference; September 2016]

The houses need to protect the occupants from high temperature and humidity in summer and cold and windy weather in winter. The fiberglass cement insulated for roofs and the airbubbled polythene sheet insulated for walls showed the best performance in temperature stability .Insulation is a vital aspect in these houses to accommodate thermal resistance based on external climate. But, shelters includinginsulation are generally unfolded and may be required labour and equipment. Its envelope is composed of textile materials coupled with different functional layers.[ Conference; September 2016]

\section{TRANSPORTATION/CONSTRUCTION/ERECTION}

The folding house provide easy solution for erection and dismantlement but it require skilled labours and equipment. For post-disaster conditions, it is necessary to erect a large number of shelters in a short time soon after the disaster. So, it is desirable for erection to limit the number of pieces and choose them to be light weight. Anchorage of some housing systems can be a challenge because it may need to pourconcrete for its foundation, especially on-site temporary housing. But, still such housing system may be preferred in order to avoid delays and costs of transportation as well as costs to buy foreign materials and pay external workforce .[ Conference; September 2016]

\section{Advantages}

- $\quad$ Shelter for homeless peoples in low budget

- $\quad$ To reduce the use of materials which is harmful for environment.

- $\quad$ To reduce the wastage of construction material.

- $\quad$ Temporary houses for disaster management.

- $\quad$ To increase the use of waste material for production of fiber cement board. 
Sustainability, Agri, Food and Environmental Research, (ISSN: 0719-3726), 10(X), 2022:

http://dx.doi.org/

- Very low maintenance.

- $\quad$ The structure could also function as an extension to existing house.

Disadvantages

- While handling the material care should be taken.

- $\quad$ Requires skilled labour.

\section{CONCLUSION}

The housing systems developed internationally with new materials and technologies may offer some benefits such as good-insulation, easy and quick erection, is important for post-disaster housing for avoiding delays or costs in transportation. Local renewable/recycled materials or energy efficient housing should be preferred in the future innovation housing designs. It is aimed to be suitable for local climate conditions. Demountable construction should be preferred in design phase for future uses. But, constraints such as available resources, financial issues, structural and operational concerns and maintenance issues are also equally important considerations for efficient design of temporary housing. Consequently, to develop the techniques for folding house construction, need to consider quick and economic erection. However, the importance of advanced technologies of construction, speed of construction, and low embodied energy should also be emphasized for in planning and designing of the folding house.[ Conference; September 2016]

\section{REFERENCES}

"AFAD,"19 11 2017. [Online]. Available:

https://www.afad.gov.tr/tr/2389/Cadirkentl er-Konteynerkentler.

H. Abulnour, "The post-disaster temporary dwelling: Fundamentals of provision, design and construction," Housing and Building National Research Center, pp. 10-24, 2014.

KJ Huntington, 2010. Folding:a house

Mingoya, Catherine. 2015. Building together : tiny house villages for the homeless : a comparative case study.

Nigg JM, Barnshaw J, Torres MR. 2006. Hurricane Katrina and the Flooding of New Orleans: Emergent Issues in Sheltering and Temporary Housing. The ANNALS of the American Academy of Political and Social Science. 604:113-128.

REVIEW OF DEVELOPMENTS AND NEW INNOVATIONS IN TEMPORARY HOUSING AND FOLDABLE BUILDINGS, September 2016Conference: 41st IAHS WORLD CONGRESS Sustainabilityand Innovation for the Future,At: Portugal 
Sustainability, Agri, Food and Environmental Research, (ISSN: 0719-3726), 10(X), 2022:

http://dx.doi.org/

Sagiroglu, Merve \& Memari, Ali. 2018. Learning from the Experiences of Using Different Types of Temporary Housing System

"UNHCR," 1501 2016. [Online]. Available: http://www.unhcr.org/innovation/usingg is technology-map-shelter-allocation-azraq-refugee-camp/

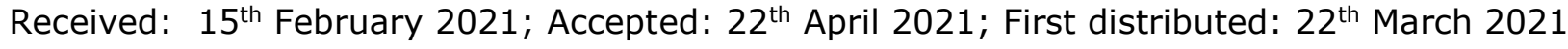

